\title{
Reoriented Investment Protocol - a Christian-ethical perspective on investments
}

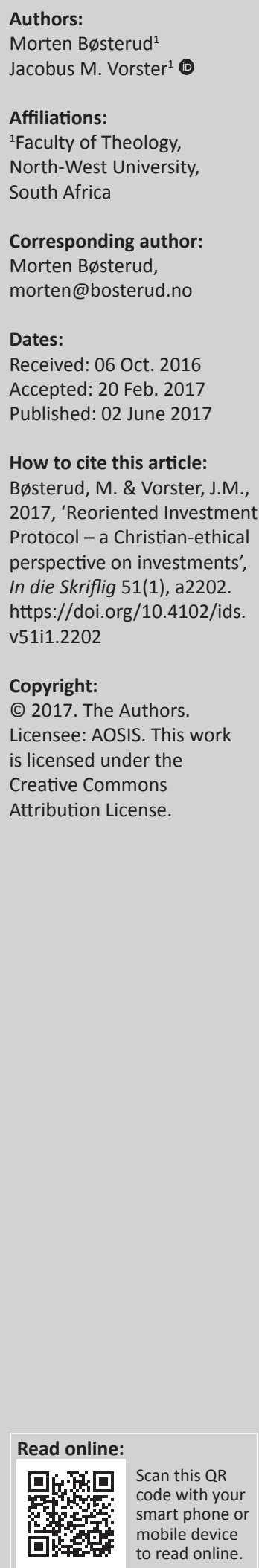

The current state of economic globalisation and attendant cross border flow of capital and investments has spurred interest for what ethically sound financial practices, which are increasing among secular politicians, investors and academics, entails. Time may have come to address this state of international financial activity from a Christian-ethical perspective. Traditional approaches, both within secular and ecclesiastical communities, have been focused on what should not be permitted to invest in from a moral standpoint. Breaking with this tradition, the authors present a creative and constructive moral approach towards investment activity where focus is on how investments may contribute to society while promoting Christian values. This new investment methodology, Reoriented Investment Protocol (RIP), is based on the reformed paradigm. It attains a systematic approach where investors need to react in alignment with constructive scripturally based ethical guidelines rather than merely avoiding immoral practices. The central argument of the article is that investments are always value-driven and never ethically neutral, and thus that investment activity should be performed under sound moral guidance from scripturally based constructive Christian-ethical guidelines.

\section{Introduction}

In an increasingly globalised economy, cross border investments are performed by actors who may be geographically distant to their investments and who may not be able to assess the societal impact caused by their investment decisions. Among some investors this problematic is taken notice of and attempts to include ethical standards for their investment practices are becoming increasingly frequent. An example here could be the Norwegian Sovereign Wealth Fund, which is one of the largest global investors with near $\$ 1$ trillion in liquid assets, and who invests according to a set of rules for ethical investments (NBIM n.d.). Guided by such budding emergence of interest in ethics by global investors, the authors question whether investments need to be guided by ethical rules and moral norms, or whether investment decisions could be value neutral in a moral perspective.

Core questions, relevant to investment activity from an ethical vantage point, are the following: Can financial investments be value free or will they always be value-driven?; What Christianethical principles are applicable to investment?; What investment categories should be avoided as counteracting Christian-ethical practice?; and What investment categories should be encouraged as promoting Christian-ethical practice? This article argues that investments are always valuedriven and it may be performed according to conventional banking principles of profitability, and yet adhere to core Christian-ethical values and norms. For achieving this end, the authors describe an investment methodology where investors may invest according to Christian-ethical norms yet remain within conventional banking paradigm. This new protocol is known as Reoriented Investment Protocol (RIP). The RIP model and its foundations within the reformed paradigm will be described below by pointing to some initial avenues of possible investments that could fall within the RIP methodology and indicating areas of further interest for developing RIP to become operationalised and useful to banking practitioners and both the academic communities of theology and business sciences (Bosterud 2015). The underlying assumption of this article is that ethical norms with divine authority can be drawn from general and specific scriptural revelation available for the practicing exegete. From this a constructive strand of ethical directions appears that are useful and practicable for present-day societal actors such as investment practitioners (Vorster 2004; 2007).

\section{Scarcity or sufficiency?}

When approaching the realm of economic philosophy and investment theory from an ethicalphilosophical perspective, a view on the larger, if not global, economic possibilities of humanity 
will be useful. A natural starting point could be whether we as humans, through our economic activity, are able to create sufficient material goods and services to fulfil all sensible human needs, or whether we are forever bound to live in a state of perpetual material scarcity.

To describe these two opposing perceptions in more detail, the principle of scarcity - the 'Scarcity Paradigm' - will be defined as the notion that resources available for human use, such as goods and services, are finite. Thus, inequality and poverty will exist in perpetuity. The principle of sufficiency the 'Sufficiency Paradigm' - will be defined as the notion that resources available for human use, such as goods and services, can be infinitely increased. Therefore, inequality and poverty only exist due to the incompetency of political systems or by societal design.

Within the central tradition of occidental economic thought, the overarching assumption has been that of inevitable resource scarcity. This powerful image still resides in large parts of current political societies in the West and is, for example, scripturally expressed in the Eden narrative (Gn 3), leading to the subsequent economic theorising and societal acceptance of inequality and material suffering (Lowry 2003). In the story of Adam and Eve being cast out of Eden, the transition from abundance in Paradise to hardship and resource scarcity is powerfully demonstrated. In this image, humans permanently have forsaken the ability to come to material fulfilment at ease, and only by strenuous work; 'By the sweat of your brow ...' (Gn 3:19), and hardship 'with painful labour you will give birth to your children' (Gn 3:16), would human life thereafter persist (Lowry 2003).

The notion of inevitable and compulsory material insufficiency commands strong power over human thought and is indeed represented in Scripture in several places, for instance through the immorality of idleness (2 Th 3:10).

In his comprehensive analysis of the19th century production and society, Karl Marx (1818-1883) developed new understandings and theories on capital creation and accumulation. For the purpose of this article, a main element in Marx's discoveries (2013) is that, in this new society, capital is no longer limited to land and other physically finite assets, but includes machines, technology and labour. Through this discovery, Marx opened up an understanding of economy that allows humanity to produce enough for everyone to live in a state of sufficiency. In a sense, as explained by Piketty (2014), Marx introduces a philosophy of potential for unlimited material growth as a possibility, but also as purpose driven by the accumulation instincts of the ruling capitalist (Zou 1994). Under this cognitive regimen of sufficiency, everyone can receive their fair share if only the distribution of the produced wealth is effective and just, and the distribution does not necessitate taking from the rich and giving to the poor, as the means of production can be perpetually replicated for all to enjoy. Galbraith (1998:102) adds to this by explaining the principles for a potential never-ending growth of capital, and thus affluence, positing that 'production - the output of the economic system' can be increased without practical limitations for human consumption.

It is my position that, because of the political and social unfairness that permeated Western society at the time of Marx and Engels, contemporary and later readers and political commentators have viewed their theories mainly as a path to material and ideological fairness through redistribution under the Scarcity Paradigm. Rather than perceiving the theories in this limiting manner, later thinkers have explained how the Marxian understanding of economic laws may involve the possibility of well-distributed affluence without mainly focusing on the agonistic aspects of redistributing already scarce resources; in other words, accepting the Sufficiency Paradigm. A premise for the RIP systematic is to accept this theory of sufficiency; leaving the mere divisional aspects connected to human material needs satisfaction outside the mandate of RIP practice and theorising.

\section{Reformed epistemology}

The Christian paradigm, elected for the RIP development, is the reformed model where central influences are drawn from Calvin (Inst), the Westminster Confessions (2010) and later reformed thinkers such as Barth (2009), Berkhof (1969) and Grudem (2013) to mention but a few. Notwithstanding these important influences, the development of Western philosophy has been substantial over the time we have known Scripture and epistemological principles have evolved alongside this development. The full scope of this development will be embedded in our common perceptions of how to know, interpret and accept reality with the on-going dualistic tension in secular philosophy where the pendulum has swung from Plato to the Enlightenment, and perhaps some way back with the postmodernists. The postmodernists have proven, more willing compared to their realist predecessors, to accept tacit meaning in observable facts and to interpret in the margins of stated expressions of reality (Foucault 2002; Derrida 1997).

Christian thinkers have certainly influenced the development of Western philosophy. Those proclaiming a different vantage point than that of Christian faith, have equally influenced Christian philosophy. The principles of hermeneutics, presented by Barth (2009) and Berkhof (1969), would not have been possible without the long-standing Western philosophical search for truth about the physical and spiritual worlds and for sources from which such insights could be drawn. Ideas pertaining to context in interpretation are equally valid whether presented by adherents to doctrinal reformed theology or by postmodernists like Foucault and his peers.

To assess investments from a Christian-ethical perspective, such as those of the RIP where the aim is to extrapolate Christian ethical principles from Scripture, mere scriptural interpretation in accordance with accepted reformed hermeneutics will not fully elucidate the broad problem 
sphere connected to investment ethics. The hermeneutical principles in use when addressing Scripture will be of guidance and inspiration when interpreting other sources, but cannot be accepted as exhaustive. It will be of great interest to apply postmodern deconstructive interpretation, techniques and semiotics when, for example, assessing what is the truth pertaining to the different companies and industries, debtors and tenant categories that could be considered as prudent areas of practical investment activity. The investment process then, after having extrapolated scriptural principles by way of hermeneutical activity as well as defined the investments and investment opportunities, will be to subsume the different investments under the relevant scriptural principles or norms. This will represent a practical exegesis as prescribed by reformed theological principles.

\section{Ethical paradigm}

For the contemporary investor, when considering ethical principles for practical use, the main philosophical directions of interest will be those of consequentialism and deontology.

\section{Consequentialism}

Consequentialist philosophy draws on utilitarianism legacy. Utilitarianism can briefly be introduced as a normative ethical school of philosophy where the aim is to maximize human utility, sometimes seen as happiness or total benefit in an anthropocentric perspective, and likewise to minimize human suffering and negative influences (Bennett 2010). The measure of utilitarianism lies in the consequences of actions and this would be seen by its proponents in a reductionist perspective where the good of the many will be preferred over the negatives of the fewer (Driver 2007).

The consequentialist ethic has received notable criticism as an applied model in society. For example, Popper (1902-1994) posited that the seeking of the best for the many would inevitably lead to totalitarianism as it would impose solutions desired by the majority on to the minority against their will. He further proposed that, instead of seeking to maximize pleasure, the aim should be to minimize pain, because, as he saw it, one man's pleasure cannot justify the pain of another (Popper 1947).

Marx criticised the consequentialist theories for not being dynamic and for assuming that human character does not change over time as well as what is perceived as good and harmful (Marx 2013).

\section{Deontology}

Opposed to consequentialism, as described above, are the deontological ethical models. A main distinguishing feature between the two lines of ethical thinking is that, for the consequentialists, the value of an action lies in its perceived outcome or consequence, and for the deontological the action itself is in focus. Deontological ethical models are sometimes referred to as legalism, because the rules of conduct are given priority over the evaluation of the consequences of conduct. God is the 'law giver' for the Christian, and the rules are revealed from Scripture through hermeneutical and exegetical activities. Consequentialism is often referred to as teleological or branded as relativism, because it assesses the goodness of an action by the relative value of its consequences, and because an action is chosen on the merit of the relative advantage of the result of one action compared to that of another (Driver 2007). For deontological ethics such evaluation is not relevant, as the action is either good or not, irrespective of its consequences (Norman 1998).

As God is the author of what are considered morally good actions from the Christian perspective, deontological models are sometimes referred to as 'divine command ethics'. By focusing on the command of God, the duty aspect of deontology is highlighted. An example that illuminates this is God's demand for Abraham to sacrifice Isaac (Gn 22:1-3), as this would be a good action according to a theory of strict obedience (Jones, Cardinal \& Hayward 2006).

From this starting point of divine command, there have been developed different versions on how to practice this principle of absolute power of God, such as situation ethics (Fletcher 1966), unqualified absolutism (Augustine 1887a; Kant 1947), conflicting absolutism (Luther 1521) and graded absolutism (Hodge 1873).

Geisler (2010) describes the latter, graded absolutism, as the suitable version to be applied under the reformed paradigm. It would therefore be prudent to present a few words on the historical background. Augustine held the position that there exists a hierarchical order of sins - some are worse than others (Augustine 1887b). To Hodge (1873), in principle, truth is sacred and all things counteracting it are in opposition to God, but he maintains that, as with the Hebrew midwives (Ex 1) and Samuel (1 Sm 16), there are scriptural foundations for the justification of wilful deception and deviation from the path of truth.

To summarise: graded absolutism entails that moral principles are derived from the absolute moral character of God and they can be divided among the higher and lower categories. When such principles are in conflict, we are bound to follow the higher moral law according to the guidelines set out above. Thus, we are not culpable for any moral transgression or otherwise held responsible for breaking the lower moral law or principle. However, what we are awarded by God are not exceptions to the rules, as these remain valid and binding, but we receive an individual exemption from suffering the consequences of sinning that would otherwise follow breaking the rule (Geisler 2010).

\section{Reformed ethics}

In consulting Scripture for ethical guidance, it is considered prudent under the reformed tradition to seek out general and specific revelation regarding ethics (Geisler 2010). A well- 
known starting point for general revelation in this deontological tradition is found in Paul's statement ( $R \mathrm{~m} 2)$ :

Indeed, when Gentiles, who do not have the law, do by nature things required by the law, they are a law for themselves, even though they do not have the law. They show that the requirements of the law are written on their hearts, their consciences also bearing witness, and their thoughts sometimes accusing them and at other times even defending them. (v. 14-15)

This is a clear example of the existence of a universal natural law, common for each member of the world's population, and is readily visible and comprehensible for all to follow. Aquinas was aware of this and, to him, the natural law pertained to the first or higher principles he considered to have universal authority and visibility without consideration of nationality or religious affiliation (Aquinas 2011). Calvin also recognised the natural law as knowable for all humans and that it was created before the Fall, indicating the divine superiority and universal status thereof as a bond between God and humans through innate conscience and standing above the laws created by humans (Inst 4.10.3; Billings 2005). To Calvin, the revelation of God is presented in natural law, clarified in Scripture and summarised in the Decalogue (Inst 2.8.12). The concept of natural law in reformed thinking has not been without contention and has gained wider acceptance in modern Neo-Calvinist theories, in particular as means to develop modern social theory under a contemporary twokingdom doctrinal view (VanDrunen 2012). Leading up to this doctrinal point was the heated debate between Karl Barth (1866-1968) and Emil Brunner (1889-1966) in the interwar period where Barth posited a Christocentric view based on the scripturally confirmed self-revelation of God in Christ, denouncing natural theology and thus the concept of natural law. Brunner's position was that of accepting the notion of natural theology, allowing the knowledge of God to be present in all humans without reference to scriptural special revelation and that, between God and humans, there is a point of contact in nature, knowable for all (Brunner \& Barth 2002; Holder 2001).

From the starting point of accepting the existence of natural law pertaining to morality, the Christian needs to seek out specific guidance towards making concrete ethical decisions from scriptural special revelation. For the reformed, the Bible represents the inscripturated divine truth of God, demonstrating the moral character of God as equally revealed in all people's hearts and in nature. An expression of this is found in 2 Timothy 3:16-17, where it is stated that 'All Scripture is God-breathed and is useful for teaching, rebuking, correcting and training in righteousness, so that the servant of God may be thoroughly equipped for every good work.'

Although not in conflict but in concert, general and special revelation are not identical. General revelation is known by and apparent to all people irrespective of religious, national or ethnic background ( $\mathrm{Rm} 2: 15)$, and all are subjected to God's judgement under this realm of revelation, as we are all 'without excuse' (Rm 1:20). Special revelation, on the other hand, is not known or apparent to all people, as it appears in the Bible, is written and 'God-breathed' (2 Tm 3:16) as well as opposed to natural law, which does not appear in such a form.

\section{Constructive ethical attitude}

As the elaboration above would have demonstrated, ethical guidance acceptable under the reformed paradigm, may be retrieved from Scripture as illuminated by general and special revelation. However, this is only a starting point for assessing what would be the practical application of such revelation and what kind of dutiful activity this induces in the believer. It is a tendency among certain reformed ethicists to let revelation be the moral guide, but yet to maintain focus on what is forbidden, rather than what is permitted. Geisler (2010) can be seen as a proponent for this line of thinking, as much of his writings focus on what would be non-acceptable as revealed from Scripture by negation. By following this line of thinking, the reader is left with an impression that, somehow, it can be the best moral option of conduct to do nothing.

Other contemporary ethicists, such as Vorster (2007), demonstrate a more constructive ethical methodology, as they search out what guidance can be found in Scripture for proactive moral societal participation in answer to the needs of individuals and groups in the collective that is our global community. An example that may illustrate the different approaches to moral questions may be drawn from the difference between how Jesus and Confucius explain the golden rule of reciprocity. Jesus says: 'So in everything, do to others what you would have them do to you, for this summarise the Law and the Prophets' (Mt 7:12), and Confucius says: 'What I do not wish others to do to me, I do not wish to do to others' (Confucius 2015). As is clearly demonstrated from this juxtaposition of the two versions, Jesus urges to action and proactivity, whereas Confucius promotes a passive approach towards others. A promotion of a proactive approach in ethical matters for Christians is found in the writings of Vorster $(2004 ; 2007)$, who, from his vantage point of post-apartheid South Africa, attains a participatory and inclusive role in the development and recreation of his nation as one of benevolence and liberal democracy. According to Vorster (2007), the aim of the Christian is to attain a constructive attitude towards society and the individual, and this is the correct path to take from a Christian ethical perspective.

The initial point of cognition for Vorster's (2007) constructive soteriological-based perspective is Scripture's revelation calling Christians to imitate the attitude of Christ in an expression of their gratitude. For example, followers are urged to take up Christ's yoke (Mt 11:29), and disciples are called to wash each other's feet (Jn 13:12-17) and to love each other as he loved them (Jn 13:34). Vorster further develops the productive ethical position from Philippians 2, which, for explanation, will be included in full: 
Have this attitude in yourselves which was also in Christ Jesus, who, although He existed in the form of God, did not regard equality with God a thing to be grasped, but emptied Himself, taking the form of a bond-servant, and being made in the likeness of men. Being found in appearance as a man, He humbled Himself by becoming obedient to the point of death, even death on a cross. For this reason also, God highly exalted Him, and bestowed on Him the name which is above every name, so that at the name of Jesus every knee will bow, of those who are in heaven and on earth and under the earth, and that every tongue will confess that Jesus Christ is Lord, to the glory of God the Father. (v. 2-11)

This powerful expression of Christian attitude, where verses 6-11 represents a hymn, forms the basis for the four main principles Vorster (2007) develops for his constructive Christian-ethical approach. The position can thus be explained as follows:

- Love. The first principle to be derived from the hymn is that of agape, or all-inclusive love, involving being humane and compassionate, and making oneself available for others in rendering comfort, dignity and respect (p. 18).

- Stewardship. The second principle is that of taking on the role of a servant, and through imitating Christ as revealed in Scripture, for example in John 13:12-17, to attain to an attitude of service for the community and thus strive for a just and moral order of peace and social justice (p. 18).

- Self-denial. The third principle is that of humility and selfdenial, in that Christians should imitate Christ in his selfdenying attitude in social relations, by exuding a willingness of personal sacrifice for the enhancement of the principles of the kingdom of God (p. 19).

- Obedience to God. The fourth principle explains that living in obedience to the will of God as expressed in Scripture entails, for Christians, seeking a chaste life and a moral social order (p. 19).

To summarise his position, Vorster (2007) explains how he perceives the above four principles as guidelines which are complementary to other hermeneutical principles of scriptural interpretation pertaining to ethics, and which he advocates to be relevant in any context and at all times.

The constructive ethical position, as explained by Vorster, has been of substantial use when developing the RIP methodology and will mainly inform the interpretations that will be presented in the following.

\section{Applicable biblical-ethical norms}

Having established the appropriate constructive ethical foundation for RIP, its application on scriptural sources will elucidate what biblical-ethical norms could be established with relevance for investment activity. These norms are debated and developed comprehensively by Vorster (2004; 2007), Geisler (2010) and Bosterud (2015). Due to limited space, this article will not refer to the abovementioned discourse in detail. Only a few topics that elaborated within this academic field, as represented by the aforementioned authors and which I find of particular interest for explaining the basic ethos of the RIP methodology, will be highlighted below.

\section{Equal opportunities: gender and minority issues}

In any society, social stratification can appear to be based on a multitude of different outer characteristics connected to ethnicity, religion, financial strength, profession, race and political affiliation, to mention but a few (Bottero 2005). In Scripture, the matter of protecting marginalised groups is described in several passages. Pertaining to the poor, it is stated in Exodus 23:6: 'Do not deny justice to your poor people in their lawsuits.' In Exodus 3:11 it is stated, as a duty, to let the poor benefit from the land in sabbatical years. A strong protection of the poor is urged in James 2:5, which reads, 'Has not God chosen those who are poor in the eyes of the world to be rich in faith and to inherit the kingdom he promised those who love him?', rendering a clarification of the biblical position toward the marginalised and poor. Another group that is mentioned frequently in Scripture is that of foreigners (Dt 15:3; Ex 18:3). In Deuteronomy 24:14 the obligation is, 'Do not take advantage of a hired worker who is poor and needy, whether that worker is a fellow Israelite or a foreigner residing in one of your towns.'

The position of women has been an area of some contention within Christian reformed circles, where some perceive the matter from a strict biblicist perspective (Vorster 2004). In particular, the Old Testament has numerous passages indicating that women are inferior in society compared to men. Examples of such sources are Exodus 20:17 where a woman is compared and likened to any other property of the husband, and Numbers 30:4-5 where the legal capacities of women are described as limited and inferior. However, these are all post-fall references and, according to Genesis 1:27, it appears that God created both genders with equal value.

In the New Testament, women's societal position has been dramatically changed and improved. For example, in Galatians 3:26-27 it is stated, 'So in Christ Jesus you are all children of God through faith, for all of you who were baptized into Christ have clothed yourselves with Christ.' To Vorster (2004) this statement is an obvious example of the New Testament expression of gender equality. He (Vorster 2004:183) continues by listing several important religious gifts that, according to his interpretation of gospel, are free and available for both genders. Vorster (2004:184) explains that within some biblicist groups it is an increasing trend to accept gender inequalities and that currently churches 'still act too much as custodians of the injustices of the past'.

\section{Fair wages}

Romans 4:4 states, 'Now to the one who works, wages are not credited as a gift but as an obligation.' From this it can be inferred that to receive a wage is a right for the worker. This is also expressed clearly in Leviticus 19:13: 'Do not defraud or rob your neighbour. Do not hold back the wages of a hired worker overnight.' From this quote, it can be inferred that 
holding back wages is akin to robbery, indicating the legitimacy of the worker's claim for his wage. In Luke 3:4 the instruction to the soldiers is to 'be content with your pay'. This instruction indicates not only that wages are due, but also that, by mentioning 'contentment', it can be inferred that the level of the wage would be sufficient for the worker (soldier) and his dependants to subsist on. How else could they be instructed to be content?

Calvin, commenting on the eighth commandment (Ex 20:15), addresses the topic of wages from the angle of the rich oppressing the poor. Calvin (Inst 2.8.45) explains:

But not to dwell too long in enumerating the different classes, we know that all the arts by which we obtain possession of the goods and money of our neighbours, for sincere affection substituting an eagerness to deceive and injure them in any way, are to be regarded as thefts. Though they may be obtained by an action at law, a different decision is given by God. He sees the long train of deception by which the man of craft begins to lay nets for his more simple neighbour, until he entangles himself in its meshes.

The above quote represents Calvin's position on market speculation, usury and oppression of the poor. He found several expressions of this in his contemporary Geneva where rich merchants exploited poor people, not least migrant workers escaping poverty in other places (Valeri 1997). It is important to note that Calvin harboured this scepticism towards unbridled capitalism, as he famously has been given the honour of inventing modern Western capitalism, not least by Weber (2012). Although Calvin viewed capitalism positively in a moderate and constructive form, his stance was one that did not promote exploitation of the weak. It should also be noted that Weber's criticism of Calvin was based not as much on Calvin's own authorship as it was on later writers in the Calvinist tradition, in particular English Puritans (Graafland 2009).

\section{Child labour}

Child labour is touched on in Article 4 of the UN Declaration of Human Rights (UN n.d.), where it is declared that 'No one shall be held in slavery or servitude; slavery and the slave trade shall be prohibited in all their forms'. In Article 24 it is said that 'Education shall be free, at least in the elementary and fundamental stages. Elementary education shall be compulsory'. It will be clear from these provisions that the described values are not in accordance with children's participation in the industrial work force. It can be reasonably inferred that all children have a right to a childhood.

From Scripture, I find of interest the statement in Matthew 19:14, 'Jesus said, "Let the little children come to me, and do not hinder them, for the kingdom of heaven belongs to such as these."' Additionally, in Romans 9:12, 'The older will serve the younger.' Both quotes tell us that no one should be 'hindered' in finding faith and that it is the obligation of the older, the parents and society, to take care of the younger, the children, and not the opposite. Both quotes indicate that the Bible gives children a protected place in the world.

The above quote, taken from Calvin, connected to exploitation of the poor and unfortunate (Calvin 2012, 2.8.45) will also serve to elucidate a perspective on child labour. Calvin took notice of adults who were being exploited in unfortunate circumstances in Geneva and, as he admonished this, it would be difficult to think that he would accept any similar or worse exploitation of children.

As education is a value, mentioned in UN (n.d.), it will be of interest to peruse some scriptural sources pertaining to education. Daniel 1:17 relates to the young and learning. It reads, 'To these four young men God gave knowledge and understanding of all kinds of literature and learning', and Ecclesiastes 7:12 states that 'Wisdom is a shelter as money is a shelter, but the advantage of knowledge is this: Wisdom preserves those who have it.' From these quotes it is clear that education is a central Christian value and knowledge has higher value than material possessions. To deprive anyone - children in particular - of education would thus not be aligned with Scripture.

It is frequently discussed whether moderate use of child labour can be beneficial to individuals and societies and, in particular, to societies undergoing economic development. The argument is that child labour can lead to the development of human resources previously not existing with the individual or the society, so that, to a certain degree, child labour can contribute to the alleviation of poverty in developing economies. However, research is scarce and ambiguous. Therefore, to conclude that child labour carries some benefits cannot be substantiated in any viable form (Akabayashi \& Psacharopoulos 1999).

\section{Animal rights}

The utilitarian, Jeremy Bentham (1748-1832), had as his ethos that the good human acts were those that increased happiness (Driver 2007). Happiness in this thinking was not merely confined to humans and animals were equally recognised as being able to experience happiness and pain (Bentham 1907). Already in Bentham's time, the topic of animals and their cognitive faculties was being discussed. To some, it was of importance whether animals could think or not to decide whether we all needed to consider how to treat them. For Bentham (1907), the question was 'not, Can they reason? nor, Can they talk? but, Can they suffer?' An important clarification that will shed further light on the matter is made by Regan (1987), who explains that animals may be subjected to suffering both by being actively inflicted with harm and by being deprived of necessary means to fulfil physical needs and satisfaction.

In contemporary philosophical discourse, Singer (1995), has become the main proponent of promoting animal welfare. To him it would be pertinent to award rights to animals akin with human rights. He builds his arguments mainly on the 
animals' capacity for feeling pain and suffering, and utilises examples from research and factory farming to draw sympathy to his philosophical stance. His argumentation fails on some points, as he is an avid vegetarian and seems to ignore the principle that if someone has rights, others have corresponding obligations to honour them. Such obligations would then rest with humans. The point to argue should rather be what obligations humans have towards animals and their suffering, and from where such obligations may be drawn. For a utilitarian like Singer, the problem then becomes that there is no higher authority from which to instil obligations in humans. His focus therefore needs to stay solely with the rights side of the discourse. Waldau (2006) on the other hand examines the connection between religion and concern for animals. His outlook is more positive, as he recognises that several world religions acknowledge the plight of some animals and that it is a human responsibility to care for nature, including our fellow beings - animals.

The obligation perspective as described above will be the most practical entry into animal rights issues and Scripture renders guidance in several passages. In Genesis 1:26-27 we learn that humans alone were created in 'the image of God' and this is generally understood in an exclusive sense - only pertaining to humanity. That animals are not created in God's image does not negate our obligations towards them. On the human obligation towards animals, we learn in Genesis 1:28 that we should 'fill the earth and subdue it. Rule over the fish in the sea and the birds in the sky and over every living creature that moves on the ground.' The use of the words subdues and rules can indicate the human duty of dominion over nature (Geisler 2010). However, even as humans are given to rule over other creatures, in Psalm 24:1 we are reminded that 'the earth is the LORD'S, and everything in it, the world, and all who live in it'. This indicates the stewardship obligation over nature that rests with humanity (Kearns 1996).

In a reformed Christian-ethical philosophy, Geisler (2010) explains that there is no place for the concept of animal rights, but maintains that we need to care for nature, as it belongs to God (Ps 24:1). Our job is to care for it, including its creatures. In my view, this is a viable position and it has to focus on the human obligation rather than the rights of other creatures that place responsibility where it is due. We have seen that Singer's theories are tainted with the lack of higher authority to care for nature, thus his focus on awarding rights, but this problem is solved within the realm of Scripture through the human obligation toward nature as God's caretakers. Animals have no other way to protect themselves than through the obligation of humans. Through these obligations, animals will not need to be subjected to impose artificial rights. Bentham's focus (1907) on the capacity to suffer and the corresponding human obligation not to inflict pain would be a pertinent guide as norm for reformed Christian ethics. A natural conclusion for the
Christian would be that the obligation is to care for animals, not to inflict suffering on them and not to deprive them of their basic, natural needs.

\section{Pollution}

From the above section it follows that it is a human obligation to care for nature, as it does not belong to us, but to God (Ps 24:1). From 1 Timothy 4:4 the goodness of nature is explained: 'For everything God created is good, and nothing is to be rejected if it is received with thanksgiving.' Paired with our duty of dominion over nature (Gn 1:28) is our obligation to be its keeper. In Genesis 2:15 the keeper aspect is revealed: 'The Lord God took the man and put him in the Garden of Eden to work it and take care of it.' To be nature's keeper involves obligations to steward God's gifts, and not to squander them. This obligation can be drawn from 1 Corinthians 4:2, 'Now it is required that those who have been given a trust must prove faithful' and Job 41:11, where God says to Job, 'Everything under heaven belongs to me.'

Vorster (2004) discusses the aspect of human stewardship in nature. He argues that important societal institutions need to be involved in caring for the natural environment. Of particular interest for this dissertation is his position that, as corporations and their stakeholders benefit from the natural environment, they should feel responsible for establishing a balance between production and environmental impact, and pollution. He continues that parts of the corporate profits should be set aside for the alleviation of its harmful effects on the environment. This is a special concern in developing countries.

Geisler (2010) supports the above position on humans' obligation to care for nature. He contends that if we sin against God's creation we also sin against ourselves and our fellow humans, as this is God's earth and God's earth is needed to sustain ourselves and our brothers and sisters, including those of the future.

\section{Consumerism}

Among Christians, consumerism has been met with scepticism, even though some links may be observed between Christian currents and increased consumerism (Trentmann 2004). To observe scriptural sources on consumerism should therefore be of interest for the topic of this article.

From Scripture we are urged in Hebrews 13:5 to 'Keep your lives free from the love of money and be content with what you have', and in Luke 12:15, 'Be on your guard against all kinds of greed; life does not consist in an abundance of possessions.' Both quotes clearly warn against overconsumption and can be seen in conjunction with our obligation to exert proper stewardship over natural resources. With direct regard to overconsumption, it is stated in Proverbs 25:16 that 'if you find honey, eat just enough - too 
much of it, and you will vomit', and in 1 Corinthians 10:31, 'So whether you eat or drink or whatever you do, do it all for the glory of God.' The latter quote demonstrates that gluttonous consumption can be seen as breaking with our keeper role in nature (Gn 2:15) and thus should be perceived as immoral.

Calvin, as explained above, may not have been opposed to capitalism, but gluttonous behaviour was not acceptable for him. On the matter of luxury, Calvin (Inst 3.10.4) wrote:

Luxury causes great care, and produces great carelessness as to virtue; and it is an old proverb: Those who are much occupied with the care of the body, usually give little care to the soul. Therefore while the liberty of the Christian in external matters is not to be tied down to a strict rule, it is, however, subject to this law-he must indulge as little as possible; on the other hand, it must be his constant aim not only to curb luxury, but to cut off all show of superfluous abundance, and carefully beware of converting a help into an hindrance.

Although the above is written in the context of gluttony and not in the context of modern mass consumption, the quote sheds valuable light on Christian thinking related to consumption and the responsible use of resources. That gluttony is considered sinful is also expressed in the Westminster Larger Catechism where it is described as a $\sin$ in connection to the seventh commandment (Westminster 2015).

\section{Immoral investment practices}

Following from interpretations of scriptural sources in accordance with the constructive ethical approach as developed above, several investment opportunities, available to the contemporary global investor, will be deemed immoral under the reformed paradigm. In Bosterud (2015), a comprehensive evaluation of such opportunities is performed. His (Bosterud 2015) findings indicate that, typically, such immoral investment practices will involve:

- Arms production as the main rule

- Medical production or services performing or promoting abortion and euthanasia

- Products or services utilising or promoting scientific or biomedical practices or products in violation of Christianethical norms

- Prison industry facilities involved in capital punishment

- Investments in unjust countries and regimes where basic human rights are not respected

- Investments involving utilising any form of child labour

- Investments supporting grave social injustice based on gender, ethnicity, race or group belonging

- Investments where labourers do not receive fair wages and work under fair working conditions

- Investments that directly or indirectly harms or alters the natural environment in a lasting manner

- Investments involving unsustainable levels of consumption

- Investments that contributes to the unnecessary infliction of pain in animals or deprives them of basic natural needs
- Investments that promotes the production, consumption or distribution of pornographic material, recreational drugs or tobacco

- Investments connected to alcohol targeting weak societal groups as consumers or to create an abusive state of consumption

- Investments connected to gambling

This list of immoral investment practices is not by any means exhaustive. For the ethically concerned investor, the assessment of practical investment opportunities against scriptural sources will be an on-going process, where cognitive agility and criticality would be at the core.

\section{Beneficial investment practices: RIP Reoriented investment protocol}

Although Christian-ethical norms may prescribe what investment practices are to be shunned, at the core of the RIP methodology lies the fact that mere adherence to these norms will not necessarily promote the best possible capital utilisation seen from a societal perspective, nor would they guide investment practices by anything but negation. The aim of RIP, then, is to seek out investment opportunities that would benefit societal interests in addition to the interests of the investors, while exerting stewardship based on Christianethical principles and to ensure that this be done by way of constructive societal participation where societally benign investment conduct is promoted (Vorster 2007).

\section{Investments Related to Women and Family}

When addressing investment opportunities that would support Christian-ethical norms of the sanctity of life, women and family considerations would be a natural starting point. The family is a core societal unit and women are at the centre of caregiving and activities connected to subsistence of life and family oriented activities. The support of these values should be given the highest priority (Kostenberger 2010). Aspects to look for as an investor would be whether investments could be seen as supporting values pertaining to the maintenance of human life and to the fulfilment of our human obligation under the creation covenant ( $\mathrm{Gn}$ 1:26).

\section{Investments promoting peace: trade and technology}

For the support of human life, counteracting war would be a central aspect to consider in investment activity. For promoting peace, I posit that it is relevant to suppress the impulse of initiating war. For humans to engage in war against someone we are friendly with is not as tempting as with those we loathe (Var, Brayley \& Korsay 1989). Consequently, it would be expected that to promote cultural exchange between people of different nationalities, races, religions and cultures would aid sustained peace and thus minimize the risk of war. Typical modes of distributing intercultural knowledge would be through travel and tourism, and investments pertaining to this could be travel 
agencies, airlines, ships and ferries, hotels, accommodation and hospitality providers.

\section{Medical service providers}

Caring for the sick is a tradition with a long history among Christians and the church. Such activity is well aligned with the scriptural position of the sanctity of life and healing of the sick (Ja 5:14). The development of hospitals stems from medieval monasteries in Europe. Knowledge of medicine was passed on and furthered in church-run universities (Antić 2010). Within this proud Christian tradition, there should be many opportunities to invest in this sector. Such investments could conceivably be directed towards shares in health service providers such as operators and owners of hospitals and clinics, insurance companies offering health coverage as well as in the form of real estate and infrastructure connected to such activities.

\section{Pharmaceuticals and medical products}

In the longstanding Christian tradition of caring for the sick, investment possibilities related to the production and distribution of products used in the health services industry and/or by patients connected to it, will be found. Typical equipment here will include CT scanners, X-ray machines, special lighting and fittings, diagnostics equipment, operating tools, prostheses, wheel chairs, hearing aids, et cetera.

\section{Health promoting investments}

In addition to the conventionally defined medical sector, there is a growing industry pertaining to promoting good health, which is expressed by way of health centres and gyms, producing and distributing specialty products, fitness technology, sporting equipment and nutritional supplements. This sector can collectively be seen as a natural extension of the medical service and product industries and is aligned with prudent Christian-ethical values, connected to the exertion of prudent societal stewardship and caring for Creation.

\section{Information technology}

Certain human rights, such as freedom of belief and freedom of speech, are core values protected under the reformed Christian-ethical paradigm. The promotion of such values should then be included in RIP investment practices. The concerned investor should seek out investments directed at this goal. Thus, to invest in software, technology and media that promote human rights is well within Christian historical tradition and would fit in under a RIP type investment strategy.

\section{New emerging nations}

Support for emergent nations in their democratic development through investment should be focused on necessary elements of infrastructure that could be missing.
Typical projects that have been performed with success in public-private partnerships (PPP) pertain to the development of roads, hospitals, schools, bridges, ports, airports and more (Savas 2000; Osborne 2002). It could be argued that contributing to the establishment of such necessary societal foundations would be an important step in securing the establishment and maintenance of basic human rights in the emergent state, as new societal upheaval could jeopardise the newfound societal goods and efficacy made possible through the PPPs.

\section{Educational service providers}

Promoting education and rendering educational services is a strong and longstanding scripturally founded Christian tradition (Dn 1:17; Ec 7:12), which is at the core of the values of the Christian church and the reformed ethical paradigm. With the advent of the internet, information technologies have been utilised to an increasing degree to support education rendered on different learning platforms. This opens up new and promising investment opportunities in addition to the direct investments into established privately owned education facilities of the traditional type.

\section{Technology production and distribution}

Technology hardware and software plays an ever more important role in all levels of education, for the days when blackboard and chalk were at the centre of educational activity are long gone. As software has been briefly discussed above, the focus here will be on the hardware and how to participate in the production and distribution of technologydriven products useful in education. Any forward-leaning investment strategy pertaining to education under a RIP based philosophy will consider such opportunities with care.

\section{Sustainable production and technology}

The Christian-ethical norms of stewardship in our interaction with society and nature under our covenant with God in Creation (Gn 1:28; 2:15) as described in the foregoing sections, can be seen as aligned with the concept of sustainability - a concept connected to the findings and propositions of the Brundtland Report in 1987 (Brundtland 1987). To invest in assets aiming at diligent resource utilisation and maintenance of the environment and manmade assets is well within Christian historical tradition and would fit in under a RIP type investment strategy.

\section{Food production: animal welfare}

To be involved in food and beverage production is to be at the core of human industrial activity (Gn 1:29; Ps 85:12). This is thus a natural sector for investors to explore. It includes industries linked to machinery, chemicals, packaging, transportation and more. A particular concern, as described above, pertains to our scripturally founded obligation to exert stewardship for animals (Gn 1:28) and not to inflict suffering on them or deprive them of their natural needs. This is an added aspect to consider when contemplating investments in 
the food production sector that is not directly linked to ecological sustainability. For the Christian, there will be a scripturally based obligation to partake only in food production that honours this obligation. Investors are equally obligated under a Christian-ethical RIP-based investment strategy.

\section{Security, law and order}

All the investment practices and categories mentioned above under the RIP systematic would be expected to benefit several parts of society and at least indirectly benefit the social order and morality. To single out certain investment categories pertaining directly to the moral order of society could be challenging, but any activity supporting the moral and legal order of society would fall within Christian-ethical accepted norms ( $\mathrm{Rm} \mathrm{13:1-2).} \mathrm{Consequently,} \mathrm{to} \mathrm{invest} \mathrm{in}$ prisons and correctional facilities, private security providers and attendant industries is well within Christian historical tradition and would fit in under a RIP type investment strategy.

\section{Conclusion}

As appeared above, the RIP methodology is a constructive approach to investment activity that does not allow for passive norm adherence and avoidance of immorality as prudent manner of investment. RIP advices a constructive and participatory attitude towards society pertaining investments where stewardship is at the heart of the practice and where long and short-term results and consequences for the individual and society constantly are measured against scriptural guidance. RIP research is an on-going activity for authors. We invite more participants into this field, as the current time is in a seminal and rudimentary stage.

\section{Acknowledgements Competing interests}

The authors declare that they have no financial or personal relationships which may have inappropriately influenced them in writing this article.

\section{Authors' contributions}

M.B is the main author, who did most of the research and writing. J.M.V contributed supervisory guidance and overall writing input.

\section{References}

Akabayashi, H., \& Psacharopoulos, G., 1999, 'The trade-off between child labour and human capital formation: A Tanzanian case study', The Journal of Development Studies 35(5), 120-140. https://doi.org/10.1080/00220389908422594

Antić, R., 2010, 'The role of Christianity in the development of European and Serbian medieval medicine', Archive of Oncology 18(4), 111-114. https://doi.org/10.2298/ A001004111A

Aquinas, T., 2011, 'Summa Theologica', in M.L. Morgan (ed.), Classics of moral and political theory, 5th edn. pp. 58-503, Hackett Publishing Company, Inc. Indiana.

Augustine, 1887a, Retractions, 1, ed. P. Schaff, Christian Literature Publishing Co., Buffalo. (Nicene and post-Nicene Fathers, 3),

Augustine, 1887b, Enchiridion, 1, ed. P. Schaff, Christian Literature Publishing Co., Buffalo. (Nicene and post-Nicene Fathers, 3 ).
Barth, K., 2009, Church dogmatics, ed. G.W. Bromiley \& T.F. Torrance, T\&T Clark, Edinburgh.

Bottero, W., 2005, Stratification: Social division and inequality, Routledge, New York.

Bennett, C., 2010, What is this thing called ethics? Routledge, Abingdon.

Bentham, J., 1907, An introduction to the principles of morals and legislation, Library of Economics and Liberty, viewed 1 February 2017, from http://www.econlib.org/ library/Bentham/bnthPML.html

Berkhof, L., 1969 [1950], Principles of biblical interpretation (SACRED HERMENEUTICS), 10th edn., Cushing Malloy Inc, Ann Arbor.

Billings, J.T., 2005, 'Calvin, participation and the gift: The activity of believers in union with Christ', PhD dissertation, Harvard University, Cambridge, Massachusetts, viewed 1 February 2017, from http://lib.scu.ac.kr/Weblmg/data/pdf/3204945. pdf

Bosterud, M., 2015, 'Public ownership and morality: Proposed investment guidelines of the Norwegian Sovereign Wealth Fund - A Christian ethical perspective', PhD thesis, Faculty of Theology, North-West University, Potchefstroom, viewed 1 thesis, Faculty of Theology, North-West University, Potchefstroom, viewed 1 February 2017, from http://dspace.nwu.ac.za/bitstream/hated
B\%C3\%B8sterud_M_2016.pdf?sequence=1\&isAllowed $=y$

Brundtland, G.H., 1987, Our common future: From one earth to one world, viewed 1 February 2017, from http://www.un-documents.net/our-common-future.pdf

Brunner, E. \& Barth, K., 2002, Natural theology, Wipf \& Stock Publishers, Eugene.

Calvin, J., 2012, Institutes of the Christian religion, Hendrickson Publishers Marketing LLC, Massachusetts.

Derrida, J., 1997, Of grammatology, corrected edn., John Hopkins University Press, Baltimore.

Driver, J., 2007, Ethics: the fundamentals, Blackwell Publishing, Malden.

Fletcher, J., 1966, Situation ethics: the new morality, Westminster John Knox Press, Louisville.

Foucault, M., 2002, The archaeology of knowledge, Rutledge Classics, London.

Galbraith, J.K., 1998, The affluent society, Penguin Books Ltd., London.

Geisler, N.L., 2010, Christian ethics, contemporary ethics \& options, 2nd edn., Baker Publishing Group, Grand Rapids.

Graafland, J., 2009, 'Calvin's restrictions on interest: Guidelines for the credit crisis', viewed 1 February 2017, from https://pure.uvt.nl/portal/files/1157704/ 2009-22.pdf

Grudem, W., 2013, Systematic theology: An introduction to biblical doctrine, InterVarsity Press, Nottingham.

Hodge, C., 1873, Systematic theology, Christian Classics Ethereal Library, Grand Rapids, viewed 1 February 2017, from http://www.ccel.org/ccel/hodge/theology3.pdf

Holder, R., 2001, 'Karl Barth and the legitimacy of natural theology', Themelios 26(3), 22-37.

Inst, see Calvin 2012

Jones, G., Cardinal, D. \& Hayward, J., 2006, Moral philosophy: A guide to ethical theory, Hodder Education, London.

Kant, I., 1947, The critique of practical reason, viewed 1 February 2017, from http:// www.lacanianworks.net/?p=315

Kearns, L. 1996, 'Saving the Creation: Christian environmentalism in the United States, Sociology of Religion 57(1), 55-70.

Kostenberger, A.J., 2010, God, marriage and family: Rebuilding the biblical foundation, 2nd edn., Crossway, Wheaton.

Lowry, S.T., 2003, 'Ancient and medieval economics', in J.S. Samuels, J.E. Biddle \& J.B. Davis (eds.), The History of Economic Thought, pp. 11-28, Blackwell Publishing Ltd, Malden.

Luther, M., 1521, Letter from Luther to Melanchthon, 99, transl. E.B. Flores, viewed 1 February 2017, from http://www.iclnet.org/pub/resources/text/wittenberg/ luther/letsinsbe.txt

Marx, K., 2013, Capital, Wordsworth Editions Limited, Hertfordshire.

NBIM, n.d., Home page of Norges Bank investment management, viewed 1 February 2017, from http://www.nbim.no/en/

Norman, R., 1998, The moral philosophers: an introduction to ethics, 2nd edn., Oxford University Press, Oxford.

Osborne, S., 2002, Public-private partnerships: Theory and practice in international perspective, Routledge, London.

Piketty, T., 2014, Capital in the twenty-first century, Harvard University Press, London.

Popper, K.R., 1947, The open society and its enemies, Routledge, London.

Regan, T., 1987, The case for animal rights, Springer, Netherlands.

Savas, E.S., 2000, Privatization and public-private partnerships, Chatham House, New York,

Singer, P., 1995, Animal liberation, Pimlico, London.

Trentmann, F., 2004, 'Beyond consumerism: new historical perspectives on consumption', Journal of Contemporary History 39(3), 373-401.

UN, n.d., Declaration of human rights, viewed 1 February 2017, from http://www. un.org/en/documents/udhr/

VanDrunen, D., 2012, 'The two kingdoms and the social order: Political and legal theory in light of God's covenant with Noah', Journal of Markets and Morality $14(2), 445-462$. 
Valeri, M., 1997, 'Religion, discipline, and the economy in Calvin's Geneva', The Sixteenth Century Journal, 28(1), 123-142. https://doi.org/10.2307/2543226

Var, T., Brayley, R., \& Korsay, M., 1989, 'Tourism and world peace: Case of Turkey', Annals of Tourism Research 16(2), 282-286. https://doi.org/10.1016/0160-7383 (89)90078-9

Vorster, J.M., 2004, Ethical perspectives on human rights, Potchefstroom Theological Publications, Potchefstroom.

Vorster, J.M., 2007, Christian attitude in the South African liberal democracy, Potchefstroom Theological Publications, Potchefstroom.

Waldau, P., 2006, 'Religion and animals', in P. Singer (ed.), In defense of animals: The second wave, pp. 69-87, Blackwell Publishing Ltd, Malden.
Weber, M., 2012, The Protestant ethic and the spirit of capitalism, Renaissance Classics, USA.

Westminster, 2015, The Westminster larger catechism, Christian Classics Ethereal Library, Grand Rapids, viewed 1 February 2017, from https://www.ccel.org/ccel/ anonymous/westminster2

Westminster Confessions, 2010, The Westminster confession of faith and catechisms in modern English, Evangelical Presbyterian Church, Michigan, viewed 1 February 2017, from file:///C:/Users/BSTERU 1/AppData/Local/Temp/0e425619 wcf-modern-2011-3.pdf

Zou, H.F., 1994, “'The spirit of capitalism” and long-run growth', European Journa of Political Economy 10(2), 279-293. https://doi.org/10.1016/0176-2680(94) 90020-5 